\author{
Agata Butarewicz-Głowacka \\ Wydział Pedagogiki i Psychologii, Uniwersytet w Białymstoku \\ E-MAIL: a.butarewicz@uwb.edu.pl
}

\title{
Nie(równość) szans edukacyjnych uczniów cudzoziemskich w polskiej szkole - komunikat z badań
}

\begin{abstract}
STRESZCZENIE
W artykule poruszam kwestię kształcenia uczniów cudzoziemskich w polskim systemie oświatowym. Uważam, że pomimo zapewnienia o równości szans edukacyjnych uczniów cudzoziemskich w polskim prawie, w praktyce szanse tych uczniów są znacznie mniejsze niż polskich obywateli, zwłaszcza ze względu na barierę językową, a także niedostateczne przygotowanie szkół i nauczycieli do kształcenia migrantów. Potwierdzeniem tej tezy są wyniki moich badań przeprowadzonych z nauczycielami pracującymi w białostockich szkołach podstawowych, w których uczą się dzieci cudzoziemskie. Prezentuję także rozwiązania, jakie w opinii badanych nauczycieli warto zastosować, aby wyrównać szanse edukacyjne uczniów cudzoziemskich.

SŁoWA KLUCzowe: (nie)równość szans edukacyjnych, uczniowie cudzoziemscy, migranci, szkoła, nauczyciele.
\end{abstract}

Edukacja jest podstawowym pojęciem w pedagogice, obejmującym „ogół wielowymiarowych działań oraz procesów służących wychowaniu i kształceniu osób czy grup społecznych" jako „dzieło przygotowania dzieci, młodych ludzi i dorosłych do aktywnego udziału w często nieokreślonym co do swego kierunku procesie zachodzących i często zaskakujących nas przemian”. W zmieniającym się świecie edukacja powinna być zorganizowana wokół czterech filarów kształcenia, które zostały ujęte w hasłach: uczyć się, aby wiedzieć (zdobyć narzędzia rozumienia), uczyć się, aby działać (oddziaływać na swoje środowisko), uczyć się, aby żyć wspólnie oraz uczyć się, aby być, który jest kwintesencją trzech

B. Milerski, B. Śliwerski, Pedagogika. Leksykon PWN, PWN, Warszawa 20oo, s. 54.

A. Radziewicz-Winnicki, Modernizacja niedostrzeganych obszarów rodzimej edukacji, Wydawnictwo Śląsk, Katowice 1995, s. 14. 
poprzednich ${ }^{3}$. Filary te korespondują z wiedzą, umiejętnościami i kompetencjami społecznymi, które dopiero w połączeniu ze sobą stanowią o pełnym i całościowym rozwoju człowieka. Edukacja w ujęciu formalnym odbywa się w szkole, której zadaniem jest uczenie młodego człowieka nowych umiejętności, przekazywanie wiedzy4. Obok tradycyjnego kształcenia formalnego istotną rolę odgrywa także kształcenie nieformalne, pozaszkolne, realizowane w postaci kursów, szkoleń oraz kształcenie incydentalne, będące rezultatem codziennej aktywności człowieka. Obecnie postuluje się łączenie tych trzech typów organizacyjnych kształcenia, dzięki czemu edukacja zyskuje nowy, holistyczny wymiar ${ }^{5}$. Wydaje się to niezwykle ważne w kontekście uczenia się przez całe życie.

Edukacja jest współcześnie postrzegana jako narzędzie służące rozwojowi jednostki i społeczeństwa. Zgodnie z art. 70 Konstytucji RzeczypospoliTEj PolsKiej edukacja stanowi jedno z podstawowych praw człowieka ${ }^{6}$. Zdaniem Bogusława Śliwerskiego

nie ma innej drogi do wyrównywania szans życiowych obywateli i zapewnienia im możliwości korzystania z przysługujących im praw niż danie im możliwości uzyskania jak najlepszego i jak najwyższego wykształcenia?

Edukacja jest wartością, która jest pomocna w osiągnięciu wysokiej jakości życia w wymiarze zarówno globalnym, jak i indywidualnym. Dlatego też zadaniem polityki społecznej państwa jest zapewnienie równego dostępu do edukacji wszystkim jednostkom na każdym szczeblu kształcenia.

Równość szans edukacyjnych stanowi jeden z priorytetów oświatowych wielu krajów w Europie i na świecie.

Założenia demokratyzacji szkolnictwa dotyczą między innymi zapewnienia wszystkim jednostkom równego startu w zakresie możliwości uzyskiwania wykształcenia. Oznacza to zapewnienie edukacji podobnej jakości dla wszyst-

3 Zob. Edukacja. Jest w niej ukryty skarb. Raport dla UNESCO Międzynarodowej Komisji do spraw Edukacji dla XXI wieku pod przewodnictwem J. Delorsa, UNESCO, przekł. W. Rabczuk, Warszawa 1998.

4 Zob. G. L. Gutek, Filozoficzne i ideologiczne podstawy edukacji, przekł. A. Kacmajor, A. Sulak, GWP, Gdańsk 2003.

5 Zob. S. M. Kwiatkowski, Uczenie się przez całe życie - memorandum Komisji Europejskiej, „Edukacja” 2002, nr 1.

$6 \quad$ Art. 70 Konstytucji Rzeczypospolitej Polskiej z dnia 2 kwietnia 1997 r. (Dz. U. 1997, nr 78, poz. 483).

$7 \quad$ B. Śliwerski, Demokracja w szkole - szkoła wyrównywania szans rozwojowych i edukacyjnych uczniów, [w:] Nierówność szans edukacyjnych - przyczyny, skutki, koncepcje zmian, W. Żłobicki, B. Maj (red.), Oficyna Wydawnicza Impuls, Kraków 2012, s. 19. 
kich dzieci - niezależnie od pochodzenia społecznego, płci, przynależności rasowej i etnicznej czy wyznania religijnego ${ }^{8}$.

Równość szans edukacyjnych wiąże się więc między innymi z włączaniem uczniów cudzoziemskich w struktury szkolnictwa powszechnego. Zwiększająca się mobilność współczesnych społeczeństw sprawia, że coraz więcej uczniów cudzoziemskich trafia do polskich szkół. W Białymstoku dużą grupę takich uczniów stanowią migranci przymusowi, głównie z Czeczenii, a ostatnio, w związku z sytuacją polityczną panującą w Ukrainie, również obywatele tego kraju. Rok szkolny 2014/2015, w prowadzonych przez miasto Białystok publicznych szkołach podstawowych, rozpoczęło 103 uczniów cudzoziemskich, a w szkołach gimnazjalnych $48^{9}$. Edukacja dzieci cudzoziemskich jest więc wyzwaniem, a zarazem jednym $\mathrm{z}$ ważniejszych zadań współczesnej szkoły.

Zgodnie z prawem uczniowie cudzoziemscy mają równy dostęp do edukacji w Polsce. Większość dzieci migrantów uczęszcza do szkół podstawowych w naszym kraju, znacznie mniej kontynuuje jednak naukę w gimnazjach i w szkołach ponadgimnazjalnych. Na tę sytuację wpływa wiele czynników, między innymi: niewystarczająca znajomość języka polskiego, przerwy w edukacji oraz niedostateczne przygotowanie nauczycieli i szkoły do kształcenia migrantów. Wyniki badań prowadzonych wśród białostockich nauczycieli potwierdzają brak przygotowania nauczycieli do pracy z cudzoziemcami. Za główne powody nieprzygotowania do pracy z uczniami cudzoziemskimi nauczyciele uznają dotychczasowy brak kontaktu z migrantami, bariery kulturowe oraz brak informacji na temat krajów pochodzenia dzieci, a także brak szkoleń i warsztatów przygotowujących do pracy z obcokrajowcami ${ }^{10}$.

Pomimo postulowanych ideklarowanych w polskim prawie równych szans edukacyjnych, w praktyce jednak uczniowie cudzoziemscy napotykają liczne bariery, poprzez które proces ich kształcenia nie przebiega pomyślnie. Stawiam więc tezę, że mimo zapewnienia o równości szans edukacyjnych uczniów cudzoziemskich w polskim prawie szanse tych uczniów są znacznie mniejsze niż polskich obywateli, zwłaszcza ze względu na barierę językową, a także niedostateczne przygotowanie szkół i nauczycieli do kształcenia migrantów. W celu weryfikacji tej tezy przeprowadziłam badania

8 T. Gmerek, Edukacja i nierówności społeczne. Studium porównawcze na przykładzie Anglii, Hiszpanii i Rosji, Oficyna Wydawnicza Impuls, Kraków 2011, s. 9.

9 Dane uzyskane z Departamentu Edukacji Urzędu Miasta Białystok, stan na 31.03.2015 r.

1o A. Bobaj, M. Wyszyńska, Nauczyciele edukacji wczesnoszkolnej wobec edukacji dzieci imigrantów, [w:] Wspólnoty z perspektywy edukacji międzykulturowej, J. Nikitorowicz, J. Muszyńska, M. Sobecki (red.), Trans Humana Wydawnictwo Uniwersyteckie, Białystok 2009. 
wśród nauczycieli pracujących z uczniami cudzoziemskimi w Białymstoku. Wybrane wyniki tych badań prezentuję w niniejszym artykule.

\section{Prawne aspekty kształcenia uczniów cudzoziemskich w polskiej szkole}

Pierwszym europejskim dokumentem regulującym kwestie kształcenia uczniów cudzoziemskich była Dyrektywa Rady Wspólnot Europejskich z dnia 25 lipca 1977 roku w sprawie kształcenia dzieci pracowników migrujących. Zgodnie z nią zadaniem każdego państwa przyjmującego migrantów jest zapewnienie im równego dostępu do edukacji, bezpłatnej intensywnej nauki języka kraju przyjmującego, możliwości kontynuowania nauki języka, historii, kultury i religii krajów pochodzenia oraz przygotowanie nauczycieli do pracy ze zróżnicowaną kulturowo klasą ${ }^{11}$.

Zgodnie z polskim prawem uczniowie cudzoziemscy są automatycznie włączani do systemu kształcenia na takich samych zasadach jak uczniowie polscy. Status prawny pobytu ich rodziców czy opiekunów nie ma znaczenia. Uczniowie ci mają prawo do bezpłatnej nauki do 18 . roku życia ${ }^{12}$. Formalnie więc migranci nie mają utrudnień $\mathrm{w}$ dostępie do edukacji. W polskim systemie edukacji nie są przewidziane odrębne formy kształcenia dla dzieci cudzoziemskich, w ramach tak zwanych klas wstępnych czy adaptacyjnych ${ }^{13}$. Migranci są włączani do głównego nurtu kształcenia pomimo nieznajomości języka polskiego. Ten model kształcenia migrantów określa się mianem integracji bezpośredniej ${ }^{14}$. Dzieci cudzoziemskie uczęszczają do szkół ogólnodostępnych z polskimi rówieśnikami i otrzymują wsparcie językowe podczas regularnych zajęć lekcyjnych. Nierzadko uczniowie ci są kwalifikowani do niższych klas niż wynika to $\mathrm{z}$ ich wieku. W konsekwencji zdarza się, że piętnasto- czy szesnastoletni chłopcy czeczeńscy, którzy w swojej kulturze traktowani są jak mężczyźni, trafiają do szkół podstawowych, ponieważ ich wiek biologiczny nie odpowiada ich wiedzy, uczą się więc z o kilka lat młodszymi polskimi kolegami i koleżankami. Powoduje to często konflikty między uczniami polskimi a cudzoziemskimi, wpływa także negatywnie na samopoczucie migrantów i ich trudności z odnalezieniem się wśród młodszych kolegów. Drugi model kształcenia migrantów, zwany modelem separacyjnym, zakłada,

\footnotetext{
${ }^{11}$ http://biblioteka-krk.ibe.edu.pl/opac_css/doc_num.php?explnum_id=559 [28.03.2015].

12 Ustawa z dnia 7 września 1991 r. o systemie oświaty (Dz. U. 2004, nr 256, poz. 2572 ze zm.)

13 D. Dziewulak, Systemy szkolne Unii Europejskiej, Wydawnictwo Akademickie Żak, Warszawa 1997.

14 R. Nowakowska-Siuta, Pedagogika porównawcza. Problemy, stan badań i perspektywy rozwoju, Oficyna Wydawnicza Impuls, Kraków 2014.
} 
że dzieci cudzoziemskie uczą się w oddzielnych klasach przygotowawczych, najczęściej przez okres dwunastu miesięcy, dopóki nie nauczą się języka w stopniu pozwalającym na aktywny udział w obowiązkowych zajęciach. Dzieci kształcone zgodnie z tym modelem otrzymują bardziej zindywidualizowane wsparcie, odpowiadające ich potrzebom i możliwościom. Jednocześnie mogą uczestniczyć w niektórych lekcjach razem ze wszystkimi uczniami. Są to zazwyczaj przedmioty niewymagające znajomości języka w stopniu zaawansowanym, takie jak muzyka, plastyka, wychowanie fizyczne, języki obce. W wielu krajach stosuje się podejście komplementarne, na które składają się elementy obu modeli ${ }^{15}$. Dzięki takiemu rozwiązaniu łączy się indywidualne kształcenie ucznia cudzoziemskiego $\mathrm{z}$ jego stopniową integracją z uczniami kraju przyjmującego w głównym nurcie edukacyjnym. W Polsce panuje integracyjny model kształcenia migrantów. Uczniowie cudzoziemscy muszą uczestniczyć w regularnych zajęciach szkolnych z polskimi rówieśnikami niezależnie od poziomu znajomości języka polskiego.

Podjęcie nauki przez cudzoziemców w polskich szkołach reguluje art. 94a ustawy z dnia 7 września 1991 roku o systemie oświaty ${ }^{16}$ oraz rozporządzenie Ministra Edukacji Narodowej z dnia 2 stycznia 2015 roku w sprawie warunków i trybu przyjmowania do publicznych przedszkoli, szkół i placówek osób niebędących obywatelami polskimi oraz obywateli polskich, którzy pobierali naukę w szkołach funkcjonujących w systemach oświaty innych państw, a także organizacji dodatkowej nauki języka polskiego, dodatkowych zajęć wyrównawczych oraz nauki języka i kultury kraju pochodzenia ${ }^{17}$. Cudzoziemcy korzystają z nauki i opieki we wszystkich typach publicznych przedszkoli i szkół do ukończenia 18 lat lub ukończenia szkoły ponadgimnazjalnej na warunkach dotyczących obywateli polskich ${ }^{18}$.

Polskie prawo oświatowe umożliwia obcokrajowcom podlegającym obowiązkowi szkolnemu lub obowiązkowi nauki podjęcie dodatkowej, bezpłatnej nauki języka polskiego w formie zajęć pozalekcyjnych. Za organizację nadprogramowych lekcji języka polskiego odpowiada gmina, w której mieszka

15 Ibidem.

16 Art. 94a ustawy z dnia 7 września 1991 r. o systemie oświaty (Dz. U. 2004, nr 256, poz. 2572 ze zm.).

17 Rozporządzenie Ministra Edukacji Narodowej z dnia 2 stycznia 2015 r. w sprawie warunków i trybu przyjmowania do publicznych przedszkoli, szkół i placówek osób niebędących obywatelami polskimi oraz obywateli polskich, którzy pobierali naukę w szkołach funkcjonujących w systemach oświaty innych państw, a także organizacji dodatkowej nauki języka polskiego, dodatkowych zajęć wyrównawczych oraz nauki języka i kultury kraju pochodzenia (Dz. U. 2015, poz. 31).

$18 \mathrm{https} / /$ men.gov.pl/pl/wspolpraca-miedzynarodowa/ksztalcenie-cudzoziemcow [27.03.2015]. 
cudzoziemiec. Ponadto, migranci mogą także korzystać z nieodpłatnych, fakultatywnych zajęć wyrównawczych $\mathrm{z}$ danego przedmiotu przez okres dwunastu miesięcy. Jednak łączna liczba dodatkowych godzin z języka polskiego oraz zajęć wyrównawczych nie może tygodniowo przekraczać pięciu ${ }^{19}$.

Zgodnie z polskim prawem, uczniowie cudzoziemscy objęci obowiązkiem szkolnym lub obowiązkiem nauki, którzy nie posługują się językiem polskim, mają prawo do pomocy ze strony osoby władającej językiem kraju, z którego pochodzą. Dyrektor szkoły może zatrudnić taką osobę w charakterze pomocy nauczyciela maksymalnie na dwanaście miesięcy. Dodatkowo, placówki dyplomatyczne lub konsularne krajów pochodzenia uczniów cudzoziemskich podlegających obowiązkowi szkolnemu, a także organizacje pozarządowe, mogą organizować w szkole za zgodą dyrekcji i organu prowadzącego naukę języka i kultury kraju pochodzenia migrantów ${ }^{20}$.

Pomimo możliwości, jakie daje uczniom cudzoziemskim polskie prawo oświatowe, z danych Departamentu Edukacji Urzędu Miasta Białystok wynika, że w roku szkolnym 2014/2015 zaledwie sześciu uczniów szkoły podstawowej i siedmiu uczniów gimnazjum niebędących obywatelami polskimi, korzysta $\mathrm{z}$ dodatkowej bezpłatnej nauki języka polskiego. Żaden uczeń szkoły podstawowej ani gimnazjum nie uczestniczy w dodatkowych zajęciach z języka i kultury kraju pochodzenia ani w dodatkowych zajęciach wyrównawczych $\mathrm{z}$ zakresu przedmiotów nauczania, organizowanych przez organ prowadzący szkołę $e^{21}$.

\section{Nauczyciele wobec kształcenia uczniów migrantów - komunikat z badań}

W niniejszym artykule prezentuję fragmentaryczne wyniki badań jakościowych, które wymagały zastosowania odpowiedniej procedury metodologicznej. Przedmiotem moich badań uczyniłam sytuację edukacyjną uczniów cudzoziemskich w polskiej szkole z perspektywy nauczycieli. Celem teoretycznym badań było poznanie postrzegania sytuacji uczniów cudzoziemskich przez nauczycieli. Cele praktyczne natomiast dotyczyły oceny sytuacji edukacyjnej uczniów cudzoziemskich przez nauczycieli, a także zaprojektowanie działań na rzecz poprawy szans edukacyjnych uczniów imigrantów w polskiej szkole. Sformułowałam wiele problemów badawczych, czyli pytań, na które poszukiwałam odpowiedzi. Chciałam się dowiedzieć, jak nauczyciele postrzegają sytuację edukacyjną uczniów cudzoziemskich. W celu

\footnotetext{
19 Ibidem.

20 Ibidem.

${ }^{21}$ Dane uzyskane z Departamentu Edukacji Urzędu Miasta Białystok, stan na 31.03.2015 r.
} 
doprecyzowania problemu głównego, wyodrębniłam liczne problemy szczegółowe, między innymi: jak wygląda dostęp do edukacji uczniów cudzoziemskich, na jaką pomoc mogą liczyć uczniowie migranci w szkole, jakie problemy mają ci uczniowie w szkole, jakie trudności napotykają nauczyciele pracujący z klasą zróżnicowaną kulturowo, jakie rozwiązania w zakresie kształcenia uczniów cudzoziemskich proponują nauczyciele. Istotą podejścia jakościowego w badaniach jest zasada otwartości badacza. Zgodnie z nią, nie stosuję hipotez, natomiast problem badawczy formułuję bardzo precyzyjnie, bo od niego zależą dalsze etapy badań, dobór materiału empirycznego, wybór metod zbierania i interpretowania danych ${ }^{22}$.

Badania przeprowadziłam metodą indywidualnych przypadków. Zastosowałam technikę wywiadu. Przeprowadzone w marcu 2015 roku wywiady indywidualne $\mathrm{z}$ dziesięcioma nauczycielami pracującymi w pięciu białostockich publicznych szkołach podstawowych, w których uczą się dzieci cudzoziemskie, miały charakter jawny i były częściowo ustrukturyzowane. Do zgromadzenia danych użyłam opracowanych kwestionariuszy wywiadów. Dobór próby był celowy, reprezentatywny ze względu na cechy populacji generalnej, prezentowane w badanej próbie. Próbę stanowili nauczyciele białostockich publicznych szkół podstawowych, w których uczą się dzieci imigrantów. Wszyscy badani nauczyciele to kobiety. Dwie z nich są nauczycielkami języka polskiego, jedna nauczycielką kształcenia zintegrowanego, jedna pracuje w charakterze nauczyciela wspomagającego, dwie nauczycielki pracują w świetlicy szkolnej, jedna uczy matematyki, dwie pracują w bibliotece szkolnej, ostatnia zaś jest pedagogiem szkolnym. Doświadczenie badanych nauczycielek w pracy z uczniami cudzoziemskimi jest zróżnicowane i wynosi od 5 do 20 lat.

Do analizy materiału empirycznego wykorzystałam koncepcję analizy danych jakościowych Matthew B. Milesa i A. Michaela Hubermana, która składa się z trzech współbieżnych potoków działań: redukcji danych, reprezentowania danych oraz wyprowadzania i weryfikacji wniosków ${ }^{23}$. Oprócz opisu jakościowego, użyłam także sieci do prezentacji danych.

Wszystkie badane nauczycielki twierdzą, że zgodnie z polskim prawem uczniowie cudzoziemscy mają zapewniony równy dostęp do edukacji, jednak znakomita większość badanych uważa, że w praktyce szanse migrantów są dużo mniejsze niż polskich uczniów:

${ }_{22}$ Zob. H. H. Krüger, N. Pfaff, Metody badań pedagogicznych, [w:] Pedagogika, B. Śliwerski (red.), t. 2: Pedagogika wobec edukacji, polityki oświatowej i badań naukowych, GWP, Gdańsk 2006.

${ }_{23}$ Zob. M. B. Miles, A. M. Huberman, Analiza danych jakościowych, przekł. S. Zabielski, Trans Humana Wydawnictwo Uniwersyteckie, Białystok 2000. 
w teorii obowiązujące prawo oraz dodatkowe formy wsparcia zapewniają cudzoziemcom równy dostęp do edukacji, jednak w praktyce trudno czasem mówić o równouprawnieniu w tym zakresie. Problem zasadza się na wdrażaniu przepisów prawa w życie szkolne [nauczycielka 1], nie wszyscy uczniowie cudzoziemscy znają język polski na poziomie wystarczającym do korzystania z nauki na równi $z$ rówieśnikami [nauczycielka 2], w rzeczywistości równy dostęp jest utrudniony przede wszystkim ze względu na słabe organizacyjnie przygotowanie polskich szkół do przyjęcia uczniów cudzoziemskich, niski zakres kompetencji nauczycieli w tym obszarze oraz zbyt małą liczbę dodatkowych zajęć, w których uczniowie ci mogą uczestniczyć [nauczycielka 4].

Tylko jedna nauczycielka jest zdania, że uczniowie cudzoziemscy mają równy dostęp do edukacji w Polsce.

Przepisy obowiązujące obecnie w Polsce dotyczące funkcjonowania cudzoziemców w polskim systemie oświaty, dostosowywania wymagań edukacyjnych do możliwości uczniów, zakładają równy dostęp tej grupy do edukacji. Prawo zakłada możliwość wyrównywania braków edukacyjnych oraz doskonalenie znajomości języka polskiego w szkole. Nie spotkałam się z sytuacją, aby organ prowadzący, po wcześniejszym złożeniu prośby, odmówił sfinansowania tychże zajęć [nauczycielka 5].

Ta sama badana zwraca jednak uwagę na to, że problemem jest liczba godzin przeznaczanych na te zajęcia, która nie jest zależna od liczby uczniów uczęszczających do danej szkoły.

Z wypowiedzi badanych wynika, że uczniowie cudzoziemscy uczący się w białostockich szkołach otrzymują różnorodne formy wsparcia. Mogą uczestniczyć w dodatkowych zajęciach dydaktyczno-wyrównawczych z konkretnych przedmiotów, a także w zajęciach doskonalących znajomość języka polskiego. Fundusze na tego typu zajęcia pozyskane są od organu prowadzącego szkołę, ale również od organizacji pozarządowych. Badane nauczycielki zwracają jednak uwagę na to, że dodatkowe zajęcia z języka polskiego jako obcego prowadzone są niestety tylko raz w tygodniu. Uczniowie cudzoziemscy mogą także liczyć na indywidualizację procesu kształcenia, za którą odpowiadają wszyscy nauczyciele w szkole.

W naszej szkole staramy się wyrównywać szanse edukacyjne uczniów cudzoziemskich przede wszystkim przez indywidualizację pracy z nimi w czasie zajęć [nauczycielka 1].

Ponadto, w szkołach trzech badanych nauczycielek zatrudnieni są asystenci nauczyciela, którzy pomagają rodzicom uczniów cudzoziemskich w załatwieniu formalności w szkołach, a także wspierają nauczycieli w pracy z uczniami, którzy mają kłopot ze zrozumieniem języka polskiego. Dwie 
nauczycielki podkreślają znaczenie pomocy ze strony doradców międzykulturowych, którzy wspierają uczniów polskich i cudzoziemskich, dbają także o podnoszenie poziomu wiedzy społeczności szkolnej w zakresie różnic międzykulturowych, specyfiki procesu integracji społeczno-kulturowej itd.

Ponadto, we wszystkich szkołach, w których pracują badane nauczycielki regularnie odbywają się liczne działania, których celem jest integracja dzieci polskich i cudzoziemskich. Prowadzone są także zajęcia integrujące zespół klasowy, do którego trafia uczeń cudzoziemski. Kolejną formą wsparcia, na którą mogą liczyć uczniowie cudzoziemscy jest pomoc psychologiczno-pedagogiczna na terenie szkoły, w ramach której dostosowuje się wymagania do możliwości ucznia, uczniowie migranci uczestniczą w zajęciach z pedagogiem szkolnym, a w razie potrzeby również w zajęciach korekcyjno-kompensacyjnych. Dzieci cudzoziemskie otrzymują także wsparcie materialne, między innymi w postaci stypendiów socjalnych, nieodpłatnych obiadów w stołówce szkolnej czy też darmowych pomocy szkolnych. Jedna z badanych nauczycielek zwraca uwagę na dość prozaiczną, ale jakże ważną formę wsparcia uczniów cudzoziemskich, jaką jest życzliwość i pozytywne nastawienie nauczycieli do tych uczniów. Inna podkreśla z kolei, że w jej szkole

w przypadku, gdy dany uczeń ma duże problemy z adaptacją w klasie czy też trudności edukacyjne, możliwe jest przydzielenie mu przez dyrekcję nauczyciela-opiekuna na jakiś czas, na zasadzie przesunięcia obowiązków, np. nauczyciela świetlicy [nauczycielka 3].

Pojawiające się formy wsparcia uczniów cudzoziemskich w świetle wypowiedzi badanych nauczycielek prezentuję w sieci 1.

W toku eksploracji interesowały mnie także problemy, jakich doświadczają uczniowie cudzoziemscy w opinii badanych nauczycieli. Największym problemem, zdaniem wszystkich nauczycielek, jest bariera językowa. Brak znajomości bądź niewystarczająca znajomość języka polskiego generuje kolejne problemy, między innymi edukacyjne, emocjonalne czy społeczne.

Wydaje mi się, że największym problemem jest bariera językowa. Uważają tak uczniowie cudzoziemscy, uczący się w mojej klasie. Obawiają się, że będą niezrozumiani przez innych uczniów [nauczycielka 2], trudności edukacyjne związane z niewystarczającą znajomością języka polskiego, czytanie i wykonywanie poleceń trwa dłużej niż u innych dzieci, co za tym idzie uczniowie ci otrzymują niższe wyniki ze sprawdzianów, testów [nauczycielka 1].

Inny problem sygnalizowany przez badane nauczycielki dotyczy nieznajomości polskiej kultury oraz szoku kulturowego, jakiego doświadczają cudzoziemcy, zwłaszcza ci pochodzący z odmiennych krajów. Wielu uczniów 
zajęcia wyrównawcze $\mathrm{z}$ konkretnych przedmiotów

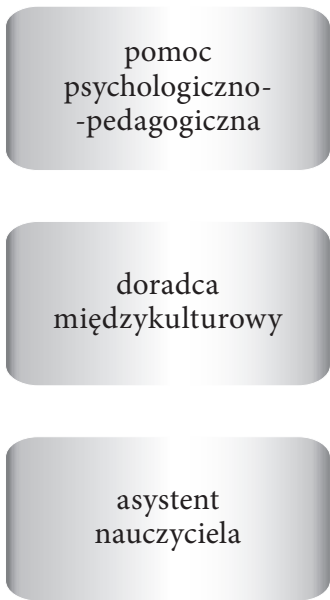

zajęcia z języka polskiego wsparcie materialne

indywidualizacja procesu kształcenia

Formy wsparcia uczniów cudzoziemskich

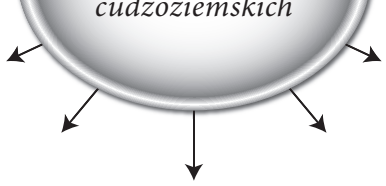

nauczyciel-opiekun życzliwość nauczycieli

Sieć 1. Różnorodność form wsparcia uczniów cudzoziemskich w szkołach badanych nauczycieli

Źródło: badania własne.

cudzoziemskich nie potrafi odnaleźć się w nowej kulturze, niektórzy potrzebują dużo czasu, by przyzwyczaić się do życia w Polsce. W przypadku uczniów o innej wierze niż chrześcijańska pojawia się także problem z obchodzeniem świąt czy też kultywowaniem tradycji.

Zdaniem badanych nauczycielek, nieznajomość polskiego systemu edukacyjnego utrudnia funkcjonowanie uczniów cudzoziemskich w polskiej szkole,

pojawiają się trudności z dostosowaniem się do różnic między systemem edukacji w Polsce a krajem, z którego pochodzą. O ile w ogóle miały dostęp do edukacji [nauczycielka 6].

Dużym problemem, zwłaszcza podczas pierwszych dni w szkole, jest także brak poczucia bezpieczeństwa w nowym otoczeniu, zagubienie i osamotnienie. Uczniowie cudzoziemcy nie znają zazwyczaj w szkole nikogo, a z opinii badanych nauczycieli wynika, że nie wszyscy polscy uczniowie odnoszą się do nich przychylnie. 
Zdarza się brak integracji ze środowiskiem szkolnym, w szczególności z kolegami i koleżankami, którzy podczas zwykłych szkolnych nieporozumień potrafią zranić najdotkliwiej, używając przezwisk związanych z problemem „inności” [nauczycielka 10].

Stereotypowe podejście polskich kolegów i koleżanek, a także ich rodziców, brak akceptacji ze strony polskich rówieśników, niewątpliwie wpływają negatywnie na samopoczucie uczniów cudzoziemskich w polskiej szkole. Wśród innych problemów uczniów cudzoziemskich, jakie obserwują badani nauczyciele pojawia się obawa przed korzystaniem z dodatkowej oferty zajęć pozalekcyjnych w szkole, brak motywacji do nauki, który związany jest z częstymi zmianami miejsc zamieszkania. Nie bez znaczenia jest także bierny stosunek rodziców cudzoziemskich do edukacji swoich dzieci. Konsekwencją tego z kolei jest niska frekwencja dzieci w szkole, a także przedwczesne wypadanie $\mathrm{z}$ systemu edukacyjnego.

Interesujących spostrzeżeń dostarcza analiza wypowiedzi badanych nauczycieli, dotyczących problemów, z jakimi borykają się w pracy ze zróżnicowaną kulturowo klasą. Większość badanych problemy te traktuje jako wyzwania. Brak podręczników do nauki języka polskiego jako obcego wymusza tworzenie i samodzielne preparowanie tekstów, testów, sprawdzianów, co jest bardzo czasochłonnym zajęciem. Kolejnym problemem, a równocześnie i wyzwaniem, jest walka ze stereotypami, która odbywa się poprzez wprowadzanie elementów edukacji międzykulturowej do programu zajęć. Trudność dla nauczycieli stanowi też brak znajomości języka polskiego, który nierzadko wpływa na izolowanie uczniów cudzoziemskich w grupie rówieśniczej. Zamiast integracji nierzadko dochodzi więc do separacji uczniów migrantów. Jedna z nauczycielek uważa, że

trudniej jest polskim uczniom, kiedy w środku roku szkolnego dołącza do klasy nowy uczeń cudzoziemiec. Jednak pewne rzeczy da się wypracować z dziećmi. Obecnie pracuję z klasą drugą i od samego początku starałam się uczyć uczniów tolerancji i akceptacji dla odmienności. Od ubiegłego roku szkolnego do chwili obecnej w klasie uczyło się 7 uczniów uchodźców. Kiedy przybywa do naszej klasy ktoś nowy, zaczynam od zabaw integracyjnych, póki dzieci nie poznają swoich imion [nauczycielka 2].

Nauczyciele zwracają też uwagę na kłopoty z ocenianiem uczniów cudzoziemskich na tle klasy. Polskie dzieci nie zawsze potrafią zrozumieć, dlaczego ich zagraniczni koledzy mają obniżone wymagania, dlaczego nauczyciele dostosowują formy i metody pracy do potrzeb dzieci cudzoziemskich. Jedna z nauczycielek długo pracowała nad przyzwyczajeniem uczniów do tego, że każdy pracuje na własnych kartach pracy. 
Stopień trudności zadań w kartach jest dostosowany do możliwości każdego dziecka. Początkowo wydawało się to dzieciom niesprawiedliwe, natomiast myślę, że już się przyzwyczaiły do zróżnicowania w tym zakresie. Trzeba też pamiętać o tym, że karty pracy przygotowywane dla uczniów cudzoziemskich muszą mieć różny stopień trudności, w zależności od stopnia rozumienia języka polskiego, długości pobytu w Polsce. Czasem jest to kilka rodzajów kart na jedne zajęcia. Trudno jest zdobyć gotowe karty pracy do pracy z uczniami, którzy nie znają języka polskiego. Przygotowanie takich kart pracy zależy od pomysłowości nauczyciela. Podobnie jest z różnymi sprawdzianami [nauczycielka 2].

Dużą trudność w opinii badanych stanowi właśnie zróżnicowanie poziomów nauczania, z którym niełatwo sobie poradzić mając w klasie ponad dwadzieścioro dzieci. Obecność w klasie uczniów cudzoziemskich o różnym stopniu znajomości języka polskiego wymaga indywidualnego podejścia do każdego dziecka. Ogromnie pomocny okazuje się drugi nauczyciel w klasie, zatrudniony $\mathrm{w}$ charakterze asystenta nauczyciela czy też nauczyciela wspomagającego. Znaczącym problemem dla wszystkich badanych nauczycielek jest niesystematyczny udział uczniów cudzoziemskich w zajęciach. Mimo podejmowanych przez nauczycieli starań, uczniowie cudzoziemscy z trudem radzą sobie z nauką, jeśli nie uczestniczą regularnie w zajęciach szkolnych. Absencja szkolna tych uczniów jest niestety zazwyczaj duża. Inny kłopot stanowi częsty brak motywacji uczniów cudzoziemskich do nauki, spowodowany zazwyczaj słabą znajomością języka polskiego. Badani nauczyciele ubolewają także nad brakiem kompetencji międzykulturowych wielu nauczycieli. Wśród innych trudności wymienianych sporadycznie przez badane nauczycielki znajdują się problemy z zachowaniem uczniów cudzoziemskich, wynikające przede wszystkim z potrzeby zwrócenia na siebie uwagi, a także negatywne nastawienie rodziców polskich uczniów wobec uczniów cudzoziemskich, którzy uczą się z ich dziećmi. Znakomitą większość uczniów cudzoziemskich w szkołach, wktórych pracują badane nauczycielki, stanowią uchodźcy, prawdopodobne jest więc to, że negatywny stosunek rodziców polskich uczniów dotyczy właśnie tej grupy migrantów, a nie wszystkich obcokrajowców. Analiza wyników moich badań w zakresie problemów doświadczanych przez uczniów cudzoziemskich oraz nauczycieli pracujących z nimi koresponduje z problemami związanymi z edukacją dzieci cudzoziemskich w Polsce, zgłaszanymi Rzecznikowi Praw Dziecka ${ }^{24}$.

Szczególnie ciekawą kategorią analityczną są propozycje działań na rzecz wyrównywania szans edukacyjnych uczniów cudzoziemskich. Zdaniem

24 A. Karaskiewicz, K. Czaj, Prawo dzieci cudzoziemskich do nauki w świetle praw dziecka, „Prawa Dziecka - Biuletyn Informacyjny Rzecznika Praw Dziecka” 2008, nr 1-2. 
badanych, należy dołożyć wszelkich starań, aby odpowiednio przygotować wszystkich pracowników szkoły do pracy z dziećmi cudzoziemskimi, nie tylko nauczycieli, ale i pracowników administracji. Należy również zapoznać całą kadrę pedagogiczną z sytuacją konkretnego ucznia cudzoziemskiego, poznać kulturę jego kraju, zwyczaje tam panujące, aby uniknąć sytuacji konfliktowych. Badane nauczycielki optują także za przeszkoleniem wszystkich nauczycieli w zakresie kompetencji międzykulturowych.

Oprócz działań na rzecz integracji dzieci polskich z cudzoziemskimi, warto włączać rodziców dzieci cudzoziemskich do społeczności szkolnej. Jeśli szkoła będzie udzielać wsparcia rodzicom uczniów cudzoziemskich, istnieje większa szansa na to, że ich dzieci będą chętniej i częściej uczęszczać do szkoły. Warto również położyć większy nacisk w programach kształcenia studentów kierunków pedagogicznych na różnorodność edukacyjną i kształcenie wielokulturowe. Badane nauczycielki zwracają także uwagę na konieczność zatrudniania asystentów międzykulturowych w szkołach, do których uczęszczają migranci, a także asystentów nauczyciela w każdej klasie, w której uczą się dzieci cudzoziemskie. Dwie nauczycielki postulują przydzielenie każdemu uczniowi cudzoziemskiemu nauczyciela wspomagającego czy też innego opiekuna.

Ogromnie ważne jest zwiększenie liczby zajęć z języka polskiego jako obcego. Brak znajomości języka powoduje, zdaniem badanych, kolejne trudności uczniów cudzoziemskich. Kurs języka polskiego powinien być bezpłatny, prowadzony w małych grupach i dostosowany do stopnia znajomości języka. Warto również zachęcić rodziców uczniów cudzoziemskich do nauki języka polskiego, dzięki czemu proces komunikowania się z nimi będzie łatwiejszy. Jedna z nauczycielek proponuje organizację kampanii społecznych na rzecz tolerancji. Inna postuluje z kolei współpracę szkół z podmiotami środowiska lokalnego, działającymi na rzecz uczniów cudzoziemskich.

Jedna z badanych nauczycielek zwraca szczególną uwagę na konieczność przygotowania klasy na przyjęcie ucznia cudzoziemskiego. Jeśli taki uczeń dołącza do klasy w trakcie roku szkolnego, można to zrobić na przykład poprzez projekt klasowy, który aktywizuje całą grupę. Zapoznanie dzieci polskich z kulturą, religią czy normami społecznymi panującymi w kraju pochodzenia nowego ucznia jest niezwykle ważne i wpływa na minimalizowanie konfliktów w klasie. Uwrażliwianie dzieci na różnice występujące pomiędzy osobami z innych krajów zapobiega, zdaniem badanych, sytuacjom nieprzyjemnym, takim jak wyśmiewanie pewnych zachowań czy przekonań.

Należy również tłumaczyć i wyjaśniać uczniom cudzoziemskim niuanse kultury, religii i zasad społecznych panujących w Polsce, aby nie czuli się zagubieni [nauczycielka 9]. 


\section{Jedna z nauczycielek uważa, że}

konieczne byłoby, zwłaszcza na początku, wyznaczenie takiemu uczniowi opiekuna klasowego, który wprowadzałby ucznia w życie szkolne czy klasowe [nauczycielka 5].

Propozycja ta wpisuje się w program „Mentoring Rówieśniczy”, który został wprowadzony do czterech białostockich szkół podstawowych, w których uczą się dzieci cudzoziemskie ${ }^{25}$. Program ten miał na celu pomoc dzieciom cudzoziemskim w polskiej szkole. Polski uczeń pełniący rolę peer mentora, jako osoba bardziej kompetentna i doświadczona, towarzyszył uczniowi - uchodźcy w adaptacji do rzeczywistości szkolnej, pomagał w nauce języka polskiego, a także wspierał go w trudnych sytuacjach. Celem programu było także promowanie mentoringu rówieśniczego jako komplementarnej względem oddziaływań nauczycieli metody pracy z jednostkami zagrożonymi wykluczeniem społecznym, w tym zdziećmi cudzoziemskimi. W sieci 2. podejmuję próbę syntetycznego przedstawienia proponowanych przez badanych nauczycieli działań, których celem jest wyrównywanie szans edukacyjnych uczniów cudzoziemskich.

\section{Zakończenie}

Uczniowie cudzoziemscy powinni być traktowani tak jak ich koledzy z kraju przyjmującego. Mimo że polskie prawo oświatowe zapewnia migrantom równe szanse edukacyjne, okazuje się, że zapewnienie to pozostaje raczej $\mathrm{w}$ sferze teorii aniżeli praktyki. Szkoły i nauczyciele nie są przygotowani do pracy z dziećmi nieznającymi języka polskiego lub znającymi go w niewystarczającym stopniu. $Z$ wypowiedzi jednej z badanych nauczycielek wynika, że

nauka języka polskiego uczniów cudzoziemskich nie zawsze jest efektywna na tyle, aby byli oni samodzielni na lekcjach. Zdarza się także, że dzieci cudzoziemskie nie uczestniczą bezpośrednio w życiu szkolnym czy klasowym, nie biorą udziału wimprezach, świętach, spotkaniach klasowych. Szkoła niestety nie zawsze jest tak otwarta i tolerancyjna wobec różnorodności swoich uczniów, jak deklaruje [nauczycielka 1].

Warto wspierać uczniów cudzoziemskich w Polsce, pamiętając o tym, że polskie dzieci, wyjeżdżając za granicę, też stają się cudzoziemcami, liczącymi na pomoc społeczności kraju przyjmującego w adaptacji do systemu eduka-

${ }_{25}$ Zob. A. Butarewicz, K. Potoniec, Mentoring rówieśniczy w szkole. Od teorii do praktycznego zastosowania wobec uczniów cudzoziemskich, Fundacja Edukacji i Twórczości, Białystok 2013. 

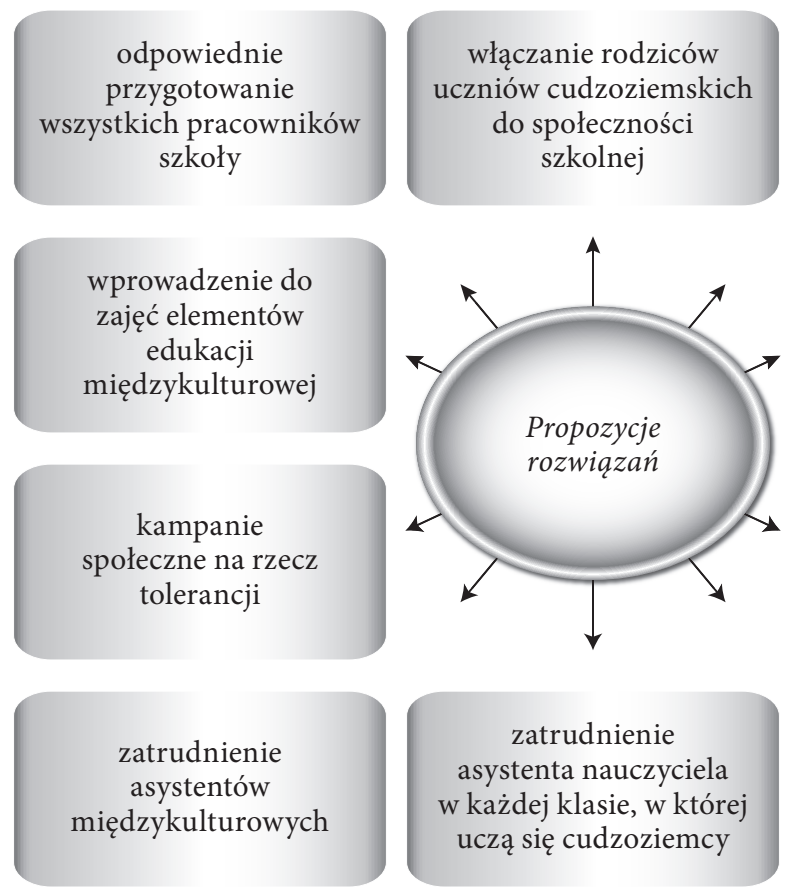

zatrudnienie asystenta nauczyciela w każdej klasie, w której uczą się cudzoziemcy współpraca

z podmiotami środowiska lokalnego

dodatkowe zajęcia $\mathrm{z}$ języka polskiego

język polski dla rodziców uczniów cudzoziemskich

nacisk na edukacjię międzykulturową na studiach pedagogicznych

Sieć 2. Propozycje działań na rzecz wyrównywania szans edukacyjnych uczniów cudzoziemskich w opinii badanych nauczycieli

Źródło: badania własne.

cyjnego tego państwa. Integracja szkolna uczniów cudzoziemskich zależy od rozwiązań systemowych szkolnictwa polskiego oraz od przygotowania nauczycieli do pracy z uczniami wywodzącymi się z innych kultur. W celu poprawy funkcjonowania uczniów cudzoziemskich w polskiej szkole, Rzecznik Praw Dziecka wysuwa wiele propozycji, między innymi: opracowanie narzędzi do pracy z dzieckiem cudzoziemskim, w tym podręczników do nauki języka polskiego, publikowanie raportów zawierających dobre praktyki oraz diagnozę sytuacji uczniów cudzoziemskich w polskiej szkole, utworzenie systemu poradnictwa prawnego i psychologicznego dla szkół, w których uczą się dzieci cudzoziemskie, powołanie zespołów roboczych złożonych m.in. z kuratorów, dyrektorów, nauczycieli, czy też włączanie przedstawicieli rodziców migrantów do rad szkolnych ${ }^{26}$. Rozwiązania te wydają się słuszne, niestety, nie jest powiedziane, kto ma się zająć ich wdrażaniem. Poza wyżej wymienionymi propozycjami, niezwykle istotna jest też edukacja całego spo-

${ }_{26}$ Zob. A. Karaskiewicz, K. Czaj, op. cit. 
łeczeństwa w zakresie edukacji międzykulturowej. Dopiero kiedy zostaną wprowadzone w życie proponowane rozwiązania, będzie można mówić o równych szansach edukacyjnych uczniów cudzoziemskich w naszym kraju nie tylko w teorii, ale również w praktyce.

\section{BIBLIOGRAFIA}

Bobaj A., Wyszyńska M., Nauczyciele edukacji wczesnoszkolnej wobec edukacji dzieci imigrantów, [w:] Wspólnoty z perspektywy edukacji międzykulturowej, J. Nikitorowicz, J. Muszyńska, M. Sobecki (red.), Trans Humana Wydawnictwo Uniwersyteckie, Białystok 2009.

Butarewicz A., Potoniec K., Mentoring rówieśniczy w szkole. Od teorii do praktycznego zastosowania wobec uczniów cudzoziemskich, Fundacja Edukacji i Twórczości, Białystok 2013.

Dziewulak D., Systemy szkolne Unii Europejskiej, Wydawnictwo Akademickie Żak, Warszawa 1997.

Edukacja. Jest w niej ukryty skarb. Raport dla UNESCO Międzynarodowej Komisji do spraw Edukacji dla XXI wieku pod przewodnictwem J. Delorsa, przekł. W. Rabczuk, UNESCO, Warszawa 1998.

Gmerek T., Edukacja i nierówności społeczne. Studium porównawcze na przykładzie Anglii, Hiszpanii i Rosji, Oficyna Wydawnicza Impuls, Kraków 2011.

Gutek G. L., Filozoficzne i ideologiczne podstawy edukacji, GWP, Gdańsk 2003.

Karaskiewicz A., Czaj K., Prawo dzieci cudzoziemskich do nauki w świetle praw dziecka, „Prawa Dziecka - Biuletyn Informacyjny Rzecznika Praw Dziecka” 2008, nr 1-2.

Krüger H. H., Pfaff N., Metody badań pedagogicznych, [w:] Pedagogika, B. Śliwerski (red.) t. 2. Pedagogika wobec edukacji, polityki oświatowej i badań naukowych, Gdańsk 2006.

Kwiatkowski S. M., Uczenie się przez całe życie - memorandum Komisji Europejskiej, „Edukacja” 2002, nr 1.

Milerski B., Śliwerski B., Pedagogika. Leksykon PWN, PWN, Warszawa 2000.

Miles M. B., Huberman A. M., Analiza danych jakościowych, przekł. S. Zabielski, Trans Humana Wydawnictwo Uniwersyteckie, Białystok 2000.

Nowakowska-Siuta R., Pedagogika porównawcza. Problemy, stan badań i perspektywy rozwoju, Kraków 2014.

Radziewicz-Winnicki A., Modernizacja niedostrzeganych obszarów rodzimej edukacji, Katowice 1995 .

Śliwerski B., Demokracja w szkole - szkoła wyrównywania szans rozwojowych i edukacyjnych uczniów, [w:] Nierówność szans edukacyjnych - przyczyny, skutki, koncepcje zmian, W. Żłobicki, B. Maj (red.), Oficyna Wydawnicza Impuls, Kraków 2012.

Konstytucja Rzeczypospolitej Polskiej z dnia 2 kwietnia 1997 r. (Dz. U. 1997, nr 78, poz. 483).

Ustawa z dnia 7 września 1991 r. o systemie oświaty (Dz. U. 2004, nr 256, poz. 2572 ze zm.).

Rozporządzenie Ministra Edukacji Narodowej z dnia 2 stycznia 2015 r. w sprawie warunków i trybu przyjmowania do publicznych przedszkoli, szkół i placówek osób niebędących obywatelami polskimi oraz obywateli polskich, którzy pobierali naukę w szkołach funkcjonujących w systemach oświaty innych państw, a także organizacji dodatkowej nauki języka polskiego, dodatkowych zajęć wyrównawczych oraz nauki języka i kultury kraju pochodzenia (Dz. U. 2015, poz. 31).

\section{ŹRÓDEA INTERNETOWE}

https://men.gov.pl/pl/wspolpraca-miedzynarodowa/ksztalcenie-cudzoziemcow http://biblioteka-krk.ibe.edu.pl/opac_css/doc_num.php?explnum_id=559 


\section{SUMMARY}

\section{In(equality) of educational opportunities for foreign students in Polish schools - the research report}

The article raises the issue of education of foreign students in the Polish education system. I believe that, despite the assurances of equality of educational opportunities for foreign students in the Polish law, in practice, the chances of these students are much smaller than the Polish citizens, especially because of the language barrier and the lack of preparation of schools and teachers to educate migrants. To confirm this thesis, the results of the research conducted with teachers working in public primary schools in Bialystok, in which foreign children study have been presented. Finally, the solutions that should be implemented, according to the surveyed teachers, to equalize educational opportunities for foreign students have been shown.

KEY WORDS: (in)equality of educational opportunities, foreign students, migrants, school, teachers. 